\title{
LEVEL II SCOUR ANALYSIS FOR BRIDGE 37 (BETHTH00070037) on TOWN HIGHWAY 7, crossing GILEAD BROOK, BETHEL, VERMONT
}

U.S. Geological Survey Open-File Report 96-233

Prepared in cooperation with

VERMONT AGENCY OF TRANSPORTATION and

FEDERAL HIGHWAY ADMINISTRATION 


\section{LEVEL II SCOUR ANALYSIS FOR BRIDGE 37 (BETHTH00070037) on TOWN HIGHWAY 7, crossing GILEAD BROOK, BETHEL, VERMONT}

By MICHAEL A. IVANOFF and MATTHEW A. WEBER

U.S. Geological Survey Open-File Report 96-233

Prepared in cooperation with

VERMONT AGENCY OF TRANSPORTATION and

FEDERAL HIGHWAY ADMINISTRATION 


\title{
U.S. DEPARTMENT OF THE INTERIOR BRUCE BABBITT, Secretary
}

\author{
U.S. GEOLOGICAL SURVEY \\ Gordon P. Eaton, Director
}

For additional information write to:

District Chief

U.S. Geological Survey 361 Commerce Way

Pembroke, NH 03275
Copies of this report may be purchased from:

U.S. Geological Survey Earth Science Information Center Open-File Reports Section Box 25286, MS 517 Federal Center

Denver, CO 80225 


\section{CONTENTS}

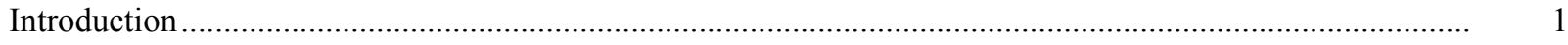

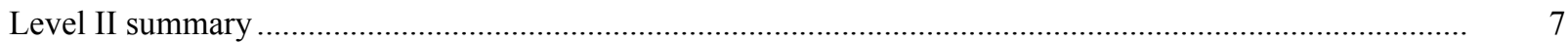

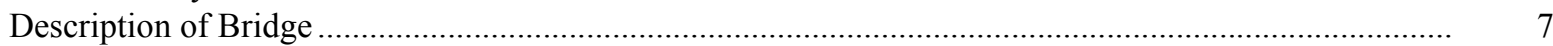

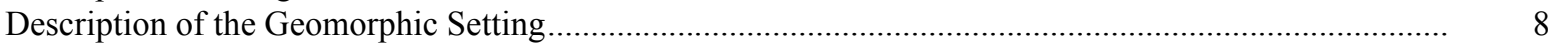

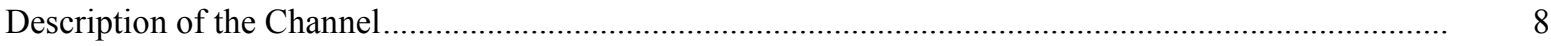

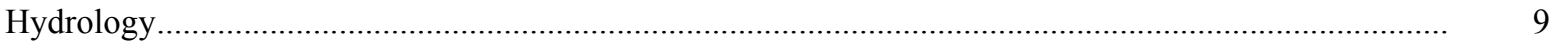

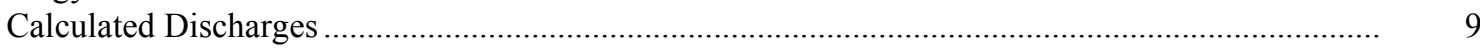

Description of the Water-Surface Profile Model (WSPRO) Analysis ......................................................... 10

Cross-Sections Used in WSPRO Analysis ......................................................................................

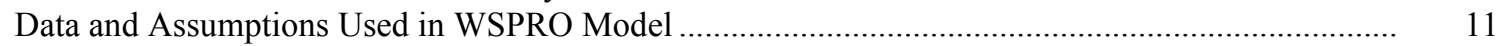

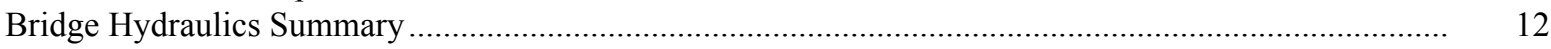

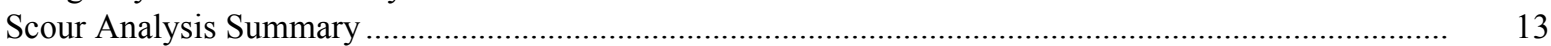

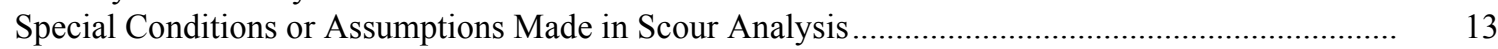

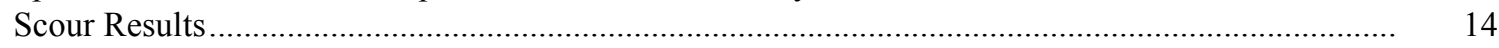

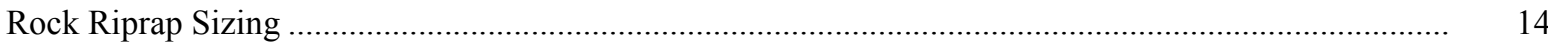

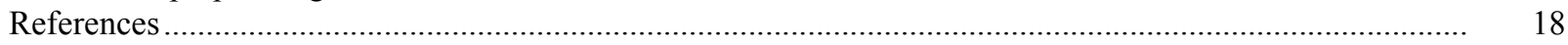

Appendixes:

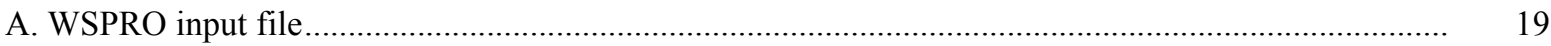

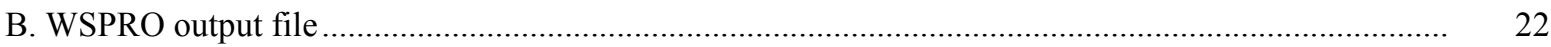

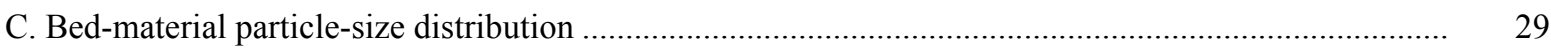

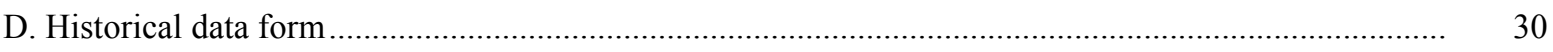

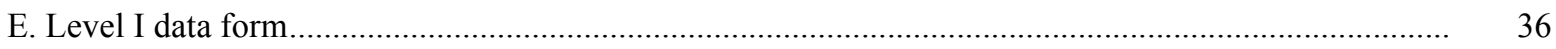

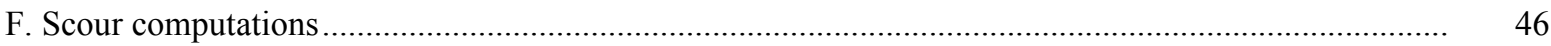

\section{FIGURES}

1. Map showing location of study area on USGS $1: 24,000$ scale map .......................................................

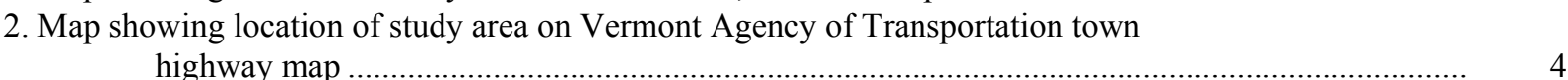

3. Structure BETHTH00070037 viewed from upstream (October 19, 1994) .................................................... 5

4. Downstream channel viewed from structure BETHTH00070037 (October 19, 1994)............................. 5

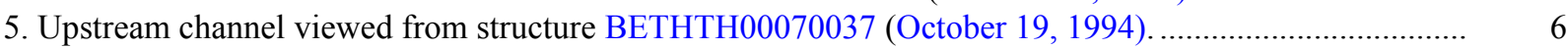

6. Structure BETHTH00070037 viewed from downstream (October 19, 1994)........................................... 6

7. Water-surface profiles for the 100- and 500-year discharges at structure

BETHTH00070037 on Town Highway 7, crossing Gilead Brook,

Bethel, Vermont.

8. Scour elevations for the 100- and 500-year discharges at structure

BETHTH00070037 on Town Highway 7, crossing Gilead Brook,

Bethel, Vermont.

\section{TABLES}

1. Remaining footing/pile depth at abutments for the 100-year discharge at structure

BETHTH00070037 on Town Highway 7, crossing Gilead Brook,

Bethel, Vermont

2. Remaining footing/pile depth at abutments for the 500-year discharge at structure

BETHTH00070037 on Town Highway 7, crossing Gilead Brook,

Bethel, Vermont 


\begin{tabular}{|c|c|c|}
\hline Multiply & By & To obtain \\
\hline \multicolumn{3}{|c|}{ Length } \\
\hline inch (in.) & 25.4 & millimeter (mm) \\
\hline foot $(\mathrm{ft})$ & 0.3048 & meter $(\mathrm{m})$ \\
\hline mile (mi) & 1.609 & kilometer (km) \\
\hline \multicolumn{3}{|c|}{ Slope } \\
\hline foot per mile ( $\mathrm{ft} / \mathrm{mi})$ & 0.1894 & meter per kilometer $(\mathrm{m} / \mathrm{km})$ \\
\hline \multicolumn{3}{|c|}{ Area } \\
\hline square mile $\left(\mathrm{mi}^{2}\right)$ & 2.590 & square kilometer $\left(\mathrm{km}^{2}\right)$ \\
\hline \multicolumn{3}{|c|}{ Volume } \\
\hline cubic foot $\left(\mathrm{ft}^{3}\right)$ & $\begin{array}{l}0.02832 \\
\text { Velocity and Flow }\end{array}$ & cubic meter $\left(\mathrm{m}^{3}\right)$ \\
\hline foot per second (ft/s) & 0.3048 & meter per second $(\mathrm{m} / \mathrm{s})$ \\
\hline cubic foot per second $\left(\mathrm{ft}^{3} / \mathrm{s}\right)$ & 0.02832 & cubic meter per second $\left(\mathrm{m}^{3} / \mathrm{s}\right)$ \\
\hline $\begin{array}{l}\text { cubic foot per second per } \\
\text { square mile } \\
{\left[\left(\mathrm{ft}^{3} / \mathrm{s}\right) / \mathrm{mi}^{2}\right]}\end{array}$ & 0.01093 & $\begin{array}{l}\text { cubic meter per } \\
\text { second per square } \\
\text { kilometer }\left[\left(\mathrm{m}^{3} / \mathrm{s}\right) / \mathrm{km}^{2}\right]\end{array}$ \\
\hline
\end{tabular}

OTHER ABBREVIATIONS

$\begin{array}{lrlr}\mathrm{BF} & \text { bank full } & \text { LWW } & \text { left wingwall } \\ \mathrm{cfs} & \text { cubic feet per second } & \text { MC } & \text { main channel } \\ \mathrm{D}_{50} & \text { median diameter of bed material } & \text { RAB } & \text { right abutment } \\ \mathrm{DS} & \text { downstream } & \text { RABUT } & \text { face of right abutment } \\ \mathrm{elev} & \text { elevation } & \text { RB } & \text { right bank } \\ \mathrm{f} / \mathrm{p} & \text { flood plain } & \text { ROB } & \text { right overbank } \\ \mathrm{ft} & \text { square feet } & \text { RWW } & \text { right wingwall } \\ \mathrm{ft} / \mathrm{ft} & \text { feet per foot } & \text { TH } & \text { town highway } \\ \mathrm{JCT} & \text { junction } & \text { UB } & \text { under bridge } \\ \mathrm{LAB} & \text { left abutment } & \text { US } & \text { upstream } \\ \mathrm{LABUT} & \text { face of left abutment } & \text { USGS } & \text { United States Geological Survey } \\ \text { LB } & \text { left bank } & \text { VTAOT Vermont Agency of Transportation } \\ \text { LOB } & \text { left overbank } & \text { WSPRO } & \text { water-surface profile model }\end{array}$

In this report, the words "right" and "left" refer to directions that would be reported by an observer facing downstream. Sea level: In this report, "sea level" refers to the National Geodetic Vertical Datum of 1929-- a geodetic datum derived from a general adjustment of the first-order level nets of the United States and Canada, formerly called Sea Level Datum of 1929.

In the appendices, the above abbreviations may be combined. For example, USLB would represent upstream left bank. 


\title{
LEVEL II SCOUR ANALYSIS FOR BRIDGE 37 (BETHTH00070037) ON TOWN HIGHWAY 7, CROSSING GILEAD BROOK, BETHEL, VERMONT
}

\author{
By Michael A. Ivanoff and Matthew A. Weber
}

\section{INTRODUCTION}

This report provides the results of a detailed Level II analysis of scour potential at structure BETHTH00070037 on town highway 7 crossing Gilead Brook, Bethel, Vermont (figures 1-8). A Level II study is a basic engineering analysis of the site, including a quantitative analysis of stream stability and scour (U.S. Department of Transportation, 1993). A Level I study is included in Appendix E of this report. A Level I study provides a qualitative geomorphic characterization of the study site. Information on the bridge available from VTAOT files were compiled prior to conducting Level I and Level II analyses and can be found in Appendix D.

The site is in the Green Mountain physiographic province of central Vermont in the town of Bethel. The $6.66-\mathrm{mi}^{2}$ drainage area is predominantly rural and forested. In the vicinity of the study site, the upstream banks have dense woody vegetation coverage and the downstream banks are grass covered.

In the study area, Gilead Brook is an incised, sinuous channel with a slope of approximately $0.017 \mathrm{ft} / \mathrm{ft}$, an average channel top width of $36 \mathrm{ft}$ and an average channel depth of $4 \mathrm{ft}$. The predominant channel bed material is cobble $\left(\mathrm{D}_{50}\right.$ is $119 \mathrm{~mm}$ or $\left.0.391 \mathrm{ft}\right)$. The geomorphic assessment at the time of the Level I and Level II site visit on October 19, 1994, indicated that the reach was laterally unstable.

The town highway 7 crossing of the Gilead Brook is a 32-ft-long, one-lane bridge consisting of one 28-foot span steel beam with timber deck (Vermont Agency of Transportation, written commun., August 24, 1994). The bridge is supported by vertical, concrete abutments with wingwalls on the upstream side. The channel is skewed approximately 35 degrees to the opening while the opening-skew-to-roadway is 30 degrees.

The left abutment footing was undermined by 0.5 feet at the time of the Level I assessment. The scour protection measures at the site included type- 2 stone fill (less than 36 inches diameter) at the upstream right and left wingwalls, and upstream side of the left and right road embankments. Additional details describing conditions at the site are included in the Level II Summary and Appendices D and E.

Scour depths and rock rip-rap sizes were computed using the general guidelines described in Hydraulic Engineering Circular 18 (Richardson and others, 1993). 
Total scour at a highway crossing is comprised of three components: 1) long-term aggradation or degradation; 2) contraction scour (due to reduction in flow area caused by a bridge) and; 3) local scour (caused by accelerated flow around piers and abutments). Total scour is the sum of the three components. Equations are available to compute scour depths for contraction and local scour and a summary of the results follows.

Contraction scour for all modelled flows was $0.0 \mathrm{ft}$. Abutment scour ranged from $8.8 \mathrm{ft}$ to $12.4 \mathrm{ft}$ and the worst-case abutment scour occurred at the 100-year discharge. Scour depths and depths to armoring are summarized on p. 14 in the section titled "Scour Results".

Scour elevations, based on the calculated depths are presented in tables 1 and 2; a graph of the scour elevations is presented in figure 8 Scour depths were calculated assuming an infinite depth of erosive material and a homogeneous particle-size distribution.

For all scour presented in this report, "the scour depths adopted [by VTAOT] may differ from the equation values based on engineering judgement" (Richardson and others, 1993, p. 21, 27). It is generally accepted that the Froehlich equation (abutment scour) gives "excessively conservative estimates of scour depths" (Richardson and others, 1993, p. 48). Many factors, including historical performance during flood events, the geomorphic assessment, and the results of the hydraulic analyses, must be considered to properly assess the validity of abutment scour results. 


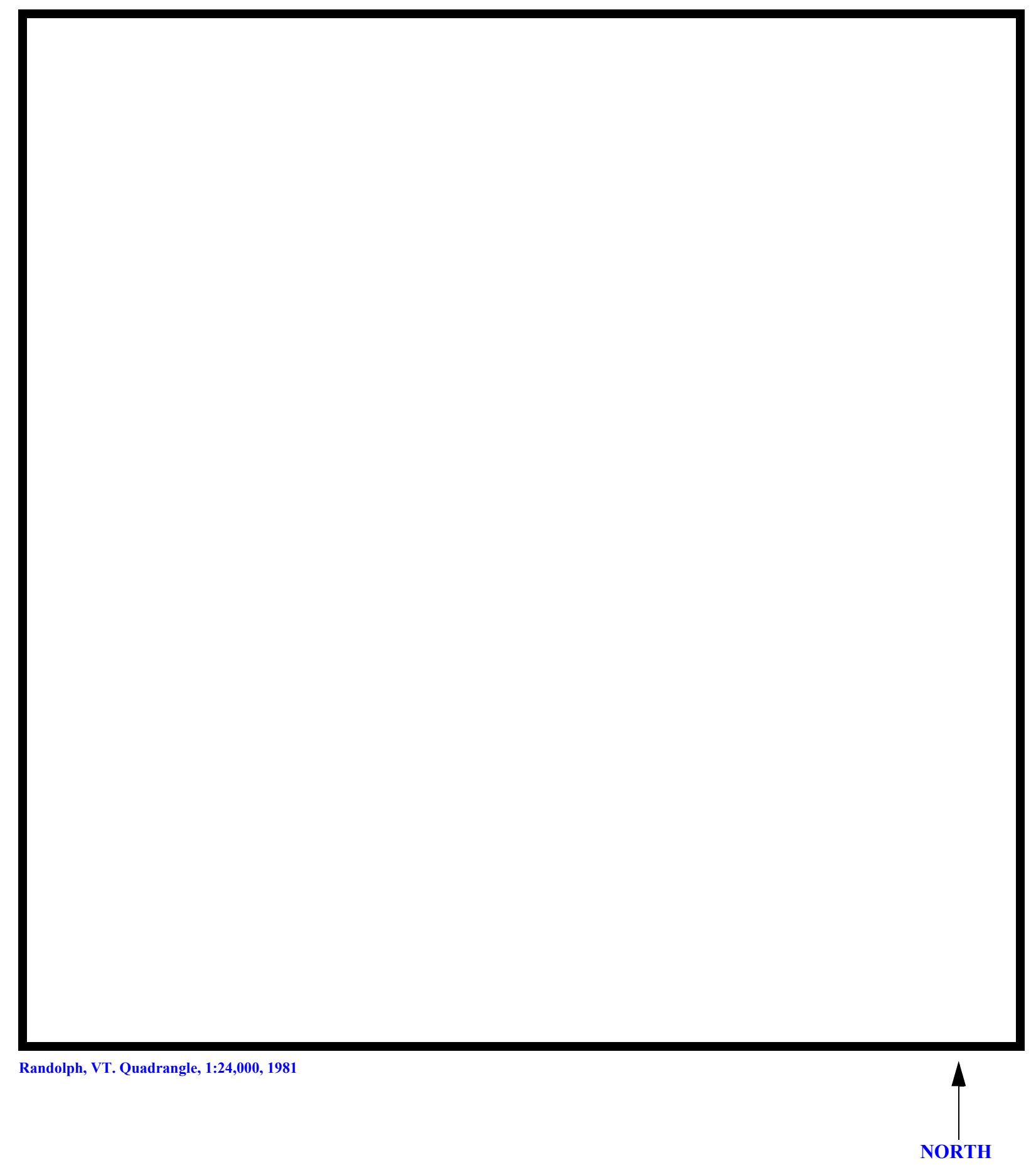

Figure 1. Location of study area on USGS 1:24,000 scale map. 
Figure 2. Location of study area on Vermont Agency of Transportation town highway map. 

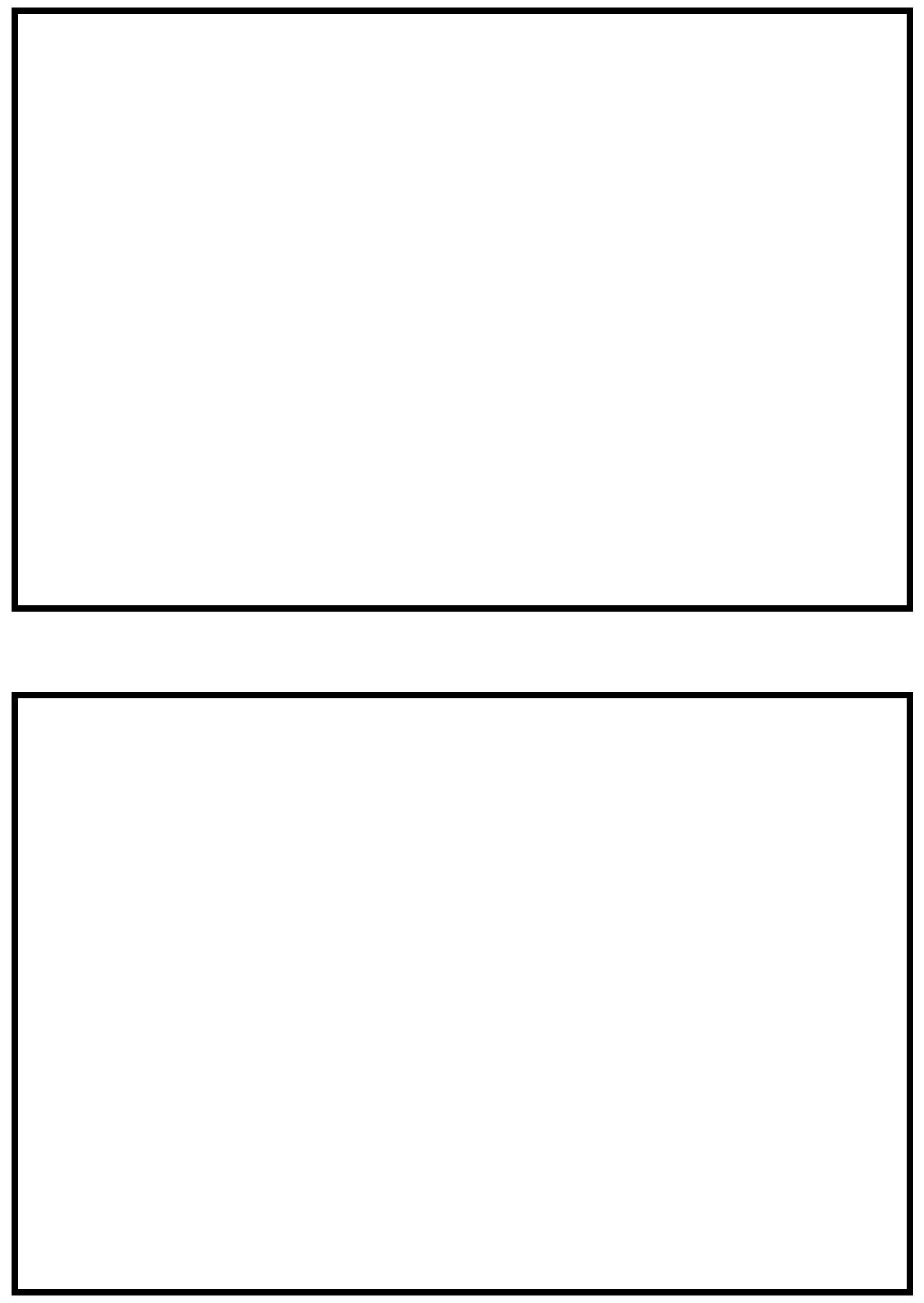

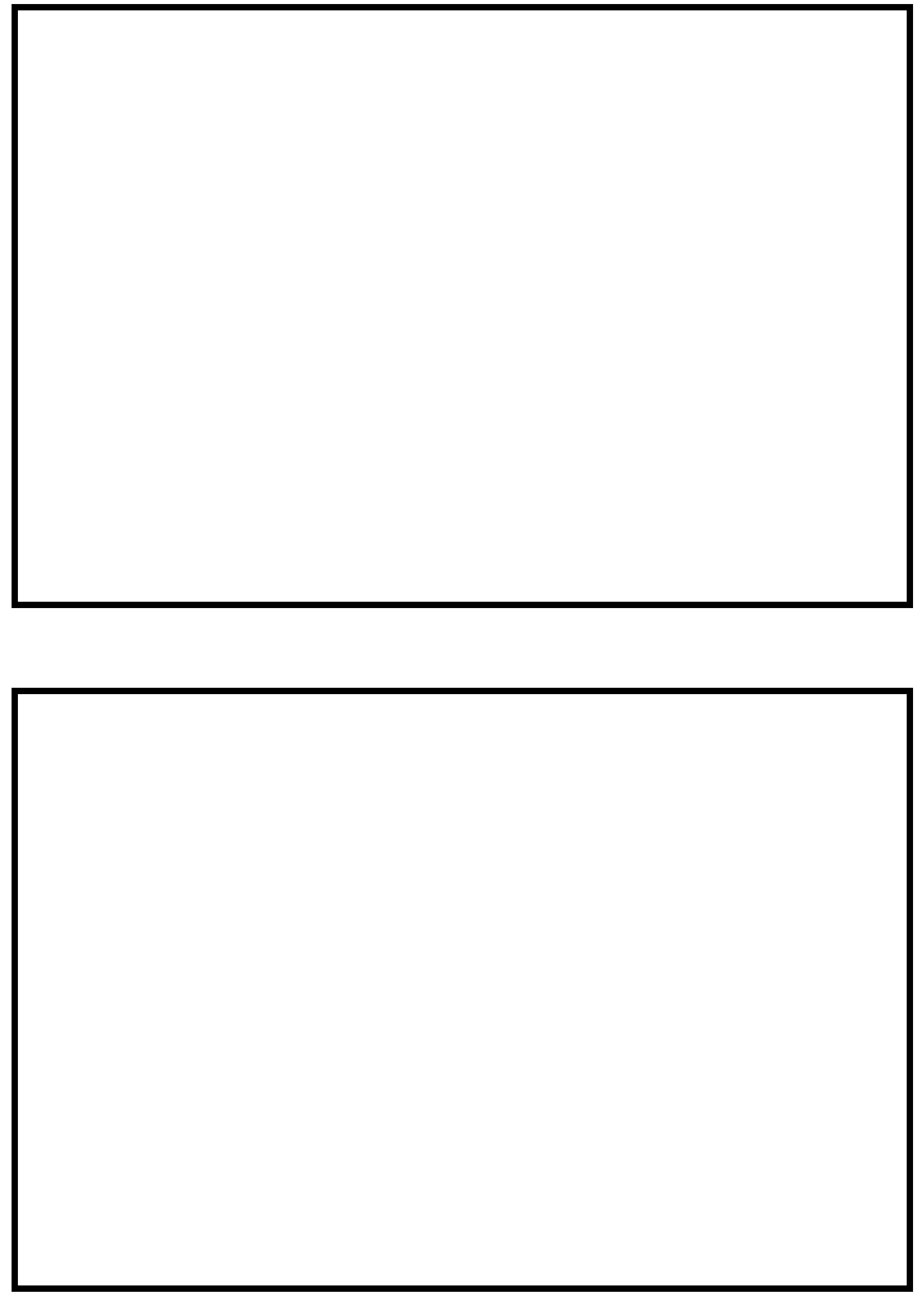


\section{LEVEL II SUMMARY}

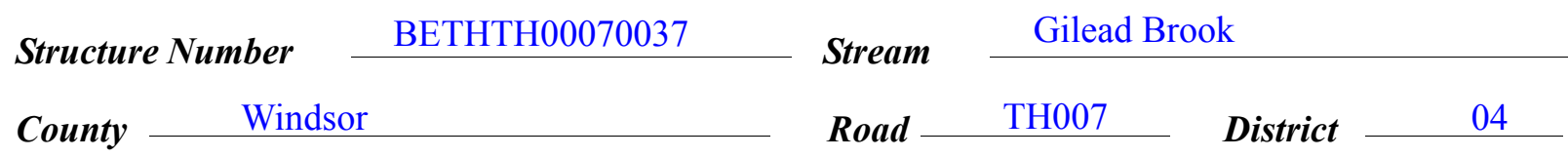

\section{Description of Bridge}

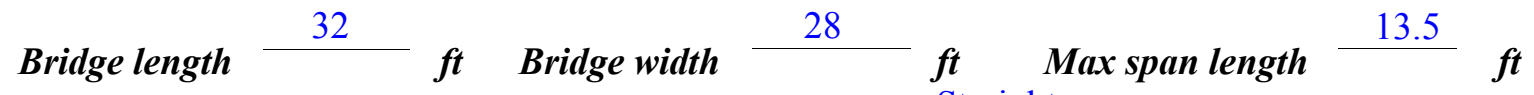
Alignment of bridge to road (on curve or straight) Abutment type

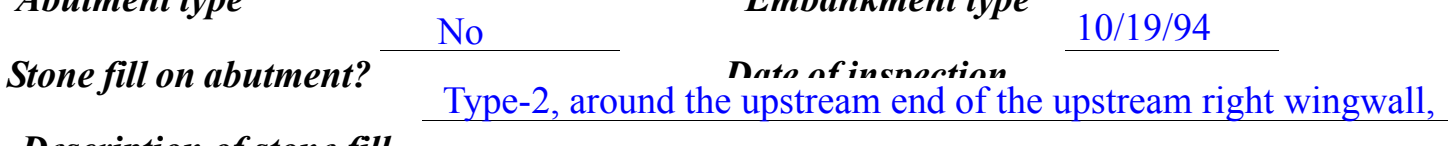
upstream left wingwall, upstream left and right bank, upstream side of the left and right road approach, and downstream side of the left road approach.

Abutments and wingwalls are concrete.

$\ldots \ldots \ldots$

\section{Y}

Is bridge skewed to flood flow according to Y ' survey? Angle

There is a moderate channel bend into the upstream bridge face.

Debris accumulation on bridge at time of Level I or Level II site visit:

\begin{tabular}{|c|c|c|c|}
\hline & $\begin{array}{c}\text { Date of incnortion } \\
10 / 19 / 94 \\
\end{array}$ & $\begin{array}{l}\text { Percent of ahmunat } \\
\text { bloeked nortzontatly }\end{array}$ & $\begin{array}{l}\text { Percent of on nel..... } \\
\text { blocked verticatty }\end{array}$ \\
\hline & $10 / 19 / 94$ & -- & -- \\
\hline & \multicolumn{3}{|c|}{ Low. There are some trees leaning over the channel upstream. } \\
\hline
\end{tabular}

Potential for debris

Dosrriho anv, fonturos noar ar at tho hridoo that mav, affort flow (includo ahsorvation dato) 


\section{Description of the Geomorphic Setting}

General topography The stream valley has a flat to slightly irregular terraces with steep valley walls on both sides.

Geomorphic conditions at bridge site: downstream (DS), upstream (US)

Date of inspection $\quad 10 / 19 / 95$

DS left: $\quad$ Moderate channel bank slope to a narrow terrace

DS right: $\quad$ Moderate channel bank slope to a narrow terrace

US left: $\quad$ Moderate channel bank slope to a narrow terrace

US right: Steep channel bank to a narrow terrace

\section{Description of the Channel}

\begin{tabular}{|c|c|c|c|}
\hline \multirow[b]{2}{*}{ Average top width } & \multirow[b]{2}{*}{$\stackrel{\boldsymbol{f}}{\mathbf{f}}$ Gravel / Cobbles } & \multirow[b]{2}{*}{ Average depth } & 3.5 \\
\hline & & & Gravel/Cobbles \\
\hline \multicolumn{2}{|c|}{ Predominant bed material } & \multicolumn{2}{|c|}{ Bank material ${ }_{\text {Sinuous and laterally }}$} \\
\hline
\end{tabular}

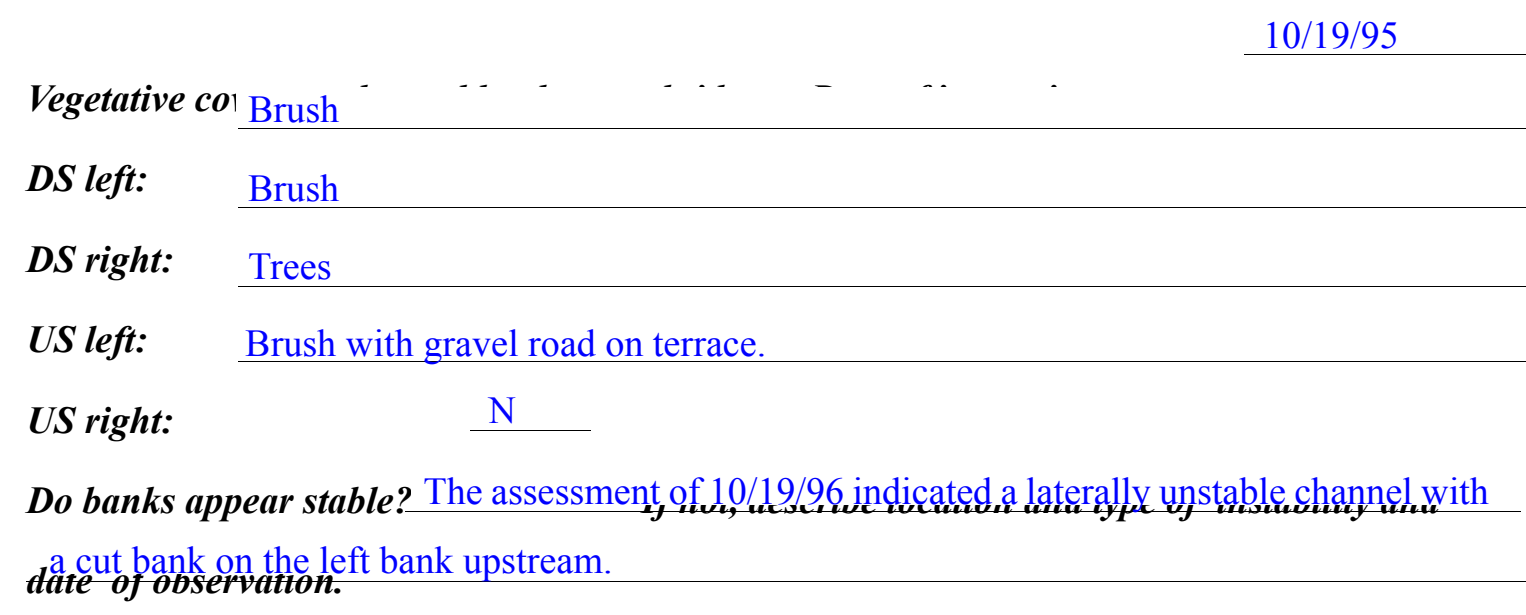

None

Describe any obstructions in channel and date of observation. 


\section{Hydrology}

Drainage area $\quad 6.66 \boldsymbol{m i}^{2}$

Percentage of drainage area in physiographic provinces: (approximate)

Physiographic province

Green Mountain
Percent of drainage area

100

Is drainage area considered rural or urban? Rural Describe any significant urbanization: There are a couple houses on the left overbank area

Is there a USGS gage on the stream of interest?

No

\section{USGS gage description}

\section{USGS gage number}

Gage drainage area

$m i^{2}$

No

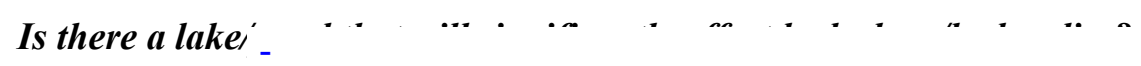

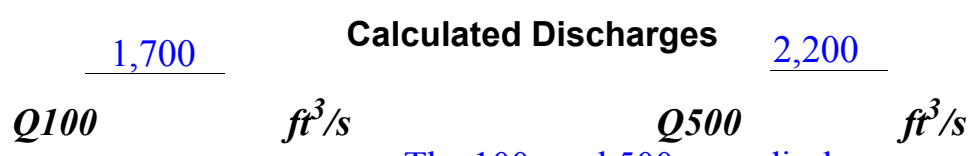

The 100- and 500-year discharges are based on an

area relationship with Bethel bridge 38 [ $[(6.7 / 8.8)$ to the 0.7 power]. Discharges at Bethel bridge 38 , which has a drainage area of 8.8 square miles, were from VTAOT files (Written commun., 1995) 


\section{Description of the Water-Surface Profile Model (WSPRO) Analysis}

Datum for WSPRO analysis (USGS survey, sea level, VTAOT plans)

USGS survey

Datum tie between USGS survey and VTAOT plans

None

Description of reference marks used to determine USGS datum. $\quad$ RM1 is a chiseled X on top of the DS end of the right abutment (elev. $496.78 \mathrm{ft}$, arbitrary datum). RM2 is a chiseled X on top of the US end of the right abutment footing (elev. $490.75 \mathrm{ft}$, arbitrary datum).

\section{Cross-Sections Used in WSPRO Analysis}

\begin{tabular}{|c|c|c|c|}
\hline${ }^{1}$ Cross-section & $\begin{array}{c}\text { Section } \\
\text { Reference } \\
\text { Distance } \\
\text { (SRD) in feet }\end{array}$ & $\begin{array}{c}{ }^{2} \text { Cross-section } \\
\text { development }\end{array}$ & Comments \\
\hline EXITX & -46 & 1 & Exit section \\
\hline FULLV & 0 & 2 & $\begin{array}{l}\text { Downstream Full-valley } \\
\text { section (Templated from } \\
\text { EXITX) }\end{array}$ \\
\hline BRIDG & 0 & 1 & Bridge section \\
\hline RDWAY & 14 & 1 & Road Grade section \\
\hline APPRO & 46 & 2 & $\begin{array}{l}\text { Modelled Approach sec- } \\
\text { tion (Templated from } \\
\text { ATEMP) }\end{array}$ \\
\hline ATEMP & 58 & 1 & $\begin{array}{l}\text { Approach section as sur- } \\
\text { veyed (Used as a tem- } \\
\text { plate) }\end{array}$ \\
\hline
\end{tabular}

${ }^{1}$ For location of cross-sections see plan-view plot included with Level I field form, Appendix E. For more detail on how cross-sections were developed see WSPRO input file. 


\section{Data and Assumptions Used in WSPRO Model}

Hydraulic analyses of the reach were done by use of the Federal Highway Administration's WSPRO step-backwater computer program (Shearman and others, 1986, and

Shearman, 1990). Results of the hydraulic model are presented in the Bridge Hydraulic Summary, Appendix B, and figure 7.

Channel roughness factors (Manning's " $\mathrm{n}$ ") used in the hydraulic model were estimated using field inspections at each cross section following the general guidelines described by Arcement, Jr. and Schneider (1989). Final adjustments to the values were made during the modelling of the reach. Channel " $\mathrm{n}$ " values for the reach ranged from 0.050 to 0.070 , and overbank " $\mathrm{n}$ " values ranged from 0.055 to 0.080 .

Normal depth at the exit section (EXITX) was assumed as the starting water surface. This depth was computed by use of the slope-conveyance method outlined in the User's manual for WSPRO (Shearman, 1990). The slope used was $0.0170 \mathrm{ft} / \mathrm{ft}$ determined by thalweg points downstream of the bridge.

The surveyed approach section (ATEMP) was moved along the approach channel slope $(0.029 \mathrm{ft} / \mathrm{ft})$ to establish the modelled approach section (APPRO), one bridge length upstream of the upstream face as recommended by Shearman and others (1986). This approach also provides a consistent method for determining scour variables.

The modeled 100-yr and 500-yr discharges overtop the left roadway embankment but not the bridge deck. The incipient overtopping discharge was determined to be $1310 \mathrm{cfs}$. 


\section{Bridge Hydraulics Summary}

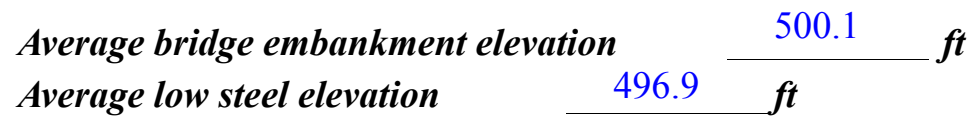

$$
\text { 100-year discharge } \quad 1,700 \quad \mathrm{ft}^{3} / \mathrm{s}
$$

Water-surface elevation in bridge opening $\quad 496.9 \quad f t$

Road overtopping? ___ Y Discharge over road _ $119, \ldots$

\begin{tabular}{llll} 
Area of flow in bridge opening & $157 \quad \boldsymbol{f t}^{2}$ \\
\cline { 2 - 3 } Average velocity in bridge opening & $9.9 \quad \mathrm{ft} / \mathrm{s}$
\end{tabular}

Maximum WSPRO tube velocity at bridge $\quad 12.6 \mathrm{ft} / \mathrm{s}$

Water-surface elevation at Approach section with bridge 499.6

Water-surface elevation at Approach section without bridge $\quad 495.4$

Amount of backwater caused by bridge

$4.2, i$

500-year discharge $\quad 2,200 \quad \mathrm{ft}^{3} / \mathrm{s}$

Water-surface elevation in bridge opening $\quad 496.9$ ft

Road overtopping? ___ Y Discharge over road__ $481, \ldots$

Area of flow in bridge opening $\quad 157 \quad \mathrm{ft}^{2}$

Average velocity in bridge opening $10.8 \mathrm{ft} / \mathrm{s}$

Maximum WSPRO tube velocity at bridge 13.7 's

Water-surface elevation at Approach section with bridge 500.4

Water-surface elevation at Approach section without bridge $\quad 496.2$

Amount of backwater caused by bridge 4.2 .

Incipient overtopping discharge $\quad 1,310 \mathrm{ft}^{3} / \mathrm{s}$

Water-surface elevation in bridge opening $496.9 \quad t$

Area of flow in bridge opening $\quad 157 \quad \mathrm{ft}^{2}$

Average velocity in bridge opening $\quad 8.3 \quad \mathrm{ft} / \mathrm{s}$

Maximum WSPRO tube velocity at bridge $10.6 \mathrm{ft} / \mathrm{s}$

Water-surface elevation at Approach section with bridge

Water-surface elevation at Approach section without bridge

498.5

Amount of backwater caused by bridge $\quad 3.9$.t 


\section{Scour Analysis Summary}

\section{Special Conditions or Assumptions Made in Scour Analysis}

Scour depths were computed using the general guidelines described in Hydraulic Engineering Circular 18 (Richardson and others, 1993). Scour depths were calculated assuming an infinite depth of erosive material and a homogeneous particle-size distribution. The results of the scour analysis are presented in tables 1 and 2 and a graph of the scour depths is presented in figure 8 .

Contraction scour was computed by use of the Chang pressure-flow scour equation (Richardson and others, 1995, p. 145-146) for the 100-year, 500-year, and incipient roadoverflow discharges. For each of the modelled discharges, there was orifice flow at the bridge. Contraction scour at bridges with orifice flow is best estimated by use of the Chang pressure-flow scour equation (oral communication, J. Sterling Jones, October 4, 1996). The results of Laursen's clear-water contraction scour equation (Richardson and others, 1995, p. 32, equation 20) were also computed and can be found in appendix F. For contraction scour computations, the average depth in the contracted section (AREA/TOPWIDTH) is subtracted from the depth of flow computed by the scour equation (Y2) to determine the actual amount of scour. Contraction scour was computed as 0.0 feet for all modeled events.

Abutment scour was computed by use of the Froehlich equation (Richardson and others, 1993, p. 49, equation 24). The Froehlich equation gives "excessively conservative estimates of scour depths" (Richardson and others, 1993, p. 48). Variables for the Froehlich equation include the Froude number of the flow approaching the embankments, the length of the embankment blocking flow, and the depth of flow approaching the embankment less any roadway overtopping. Worst case abutment scour and total scour occurs for the 100 yr model. 


\section{Scour Results}

$$
\text { 100-yr discharge 500-yr discharge }
$$

(Scour depths in feet)

Main channel

Live-bed scour

Clear-water scour

Depth to armoring

Left overbank

Right overbank

Local scour:

Abutment scour

Left abutment

Right abutment

Pier scour

Pier 1

Pier 2

Pier 3
12.4

10.2
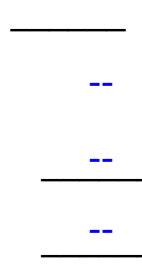

10.2

8.8
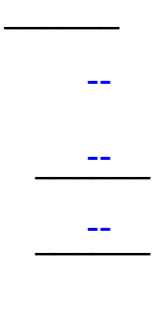

11.0

$10.0-$

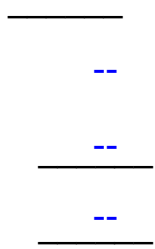

\section{Rock Riprap Sizing}

Incipient overtopping 100-yrdischarge 500-yrdischarge discharge

2.2

2.2

Left abutment

Right abutment

Piers:

Pier 1

Pier 2

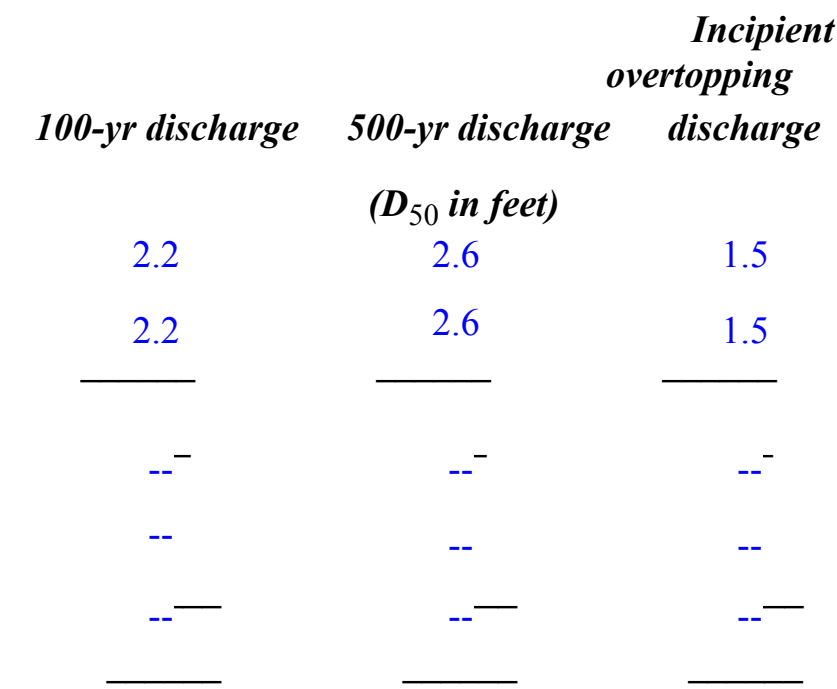




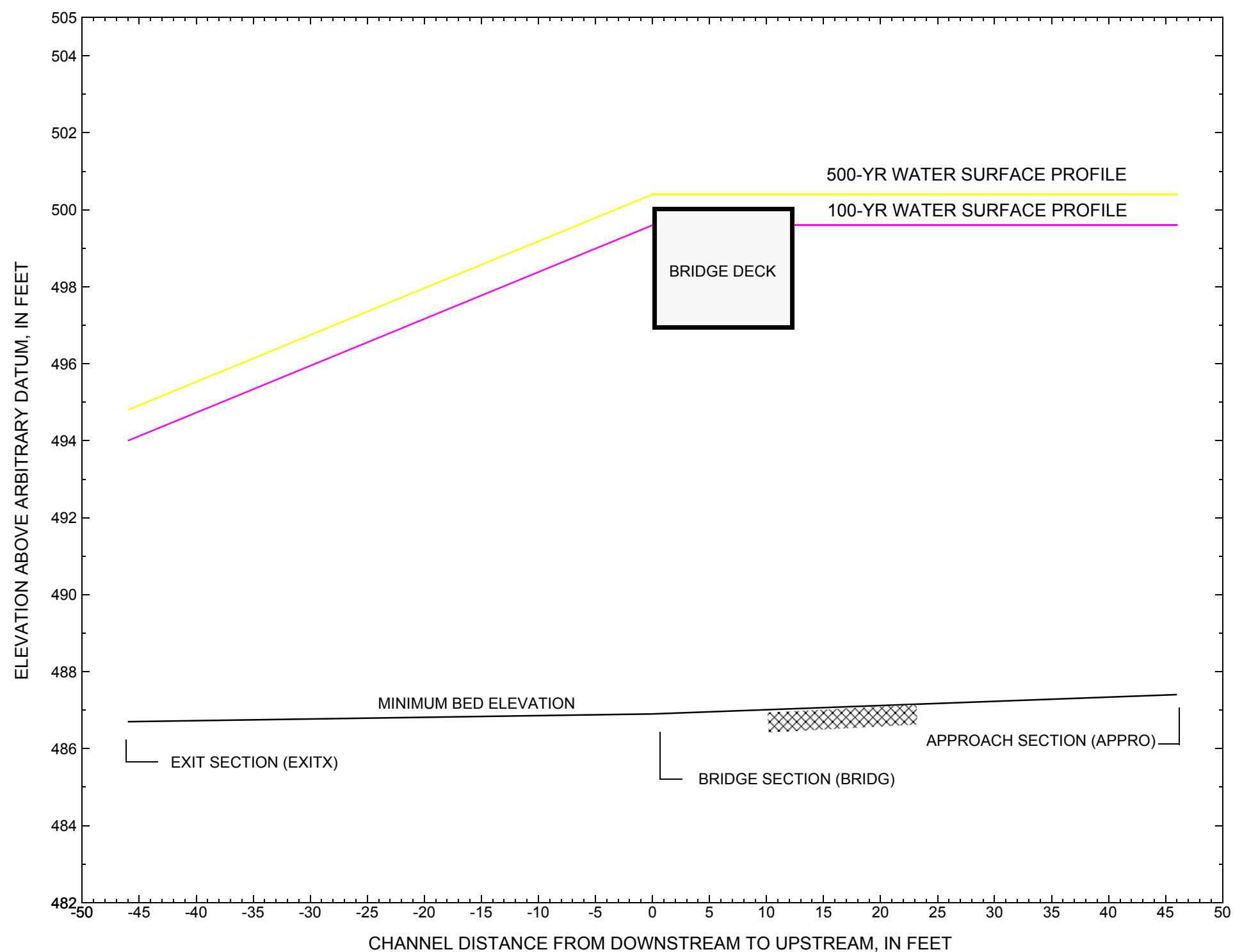

Figure 7. Water-surface profiles for the 100- and 500-yr discharges at structure BETHTH00070037 on town highway 7, crossing Gilead Brook, Bethel, Vermont. 


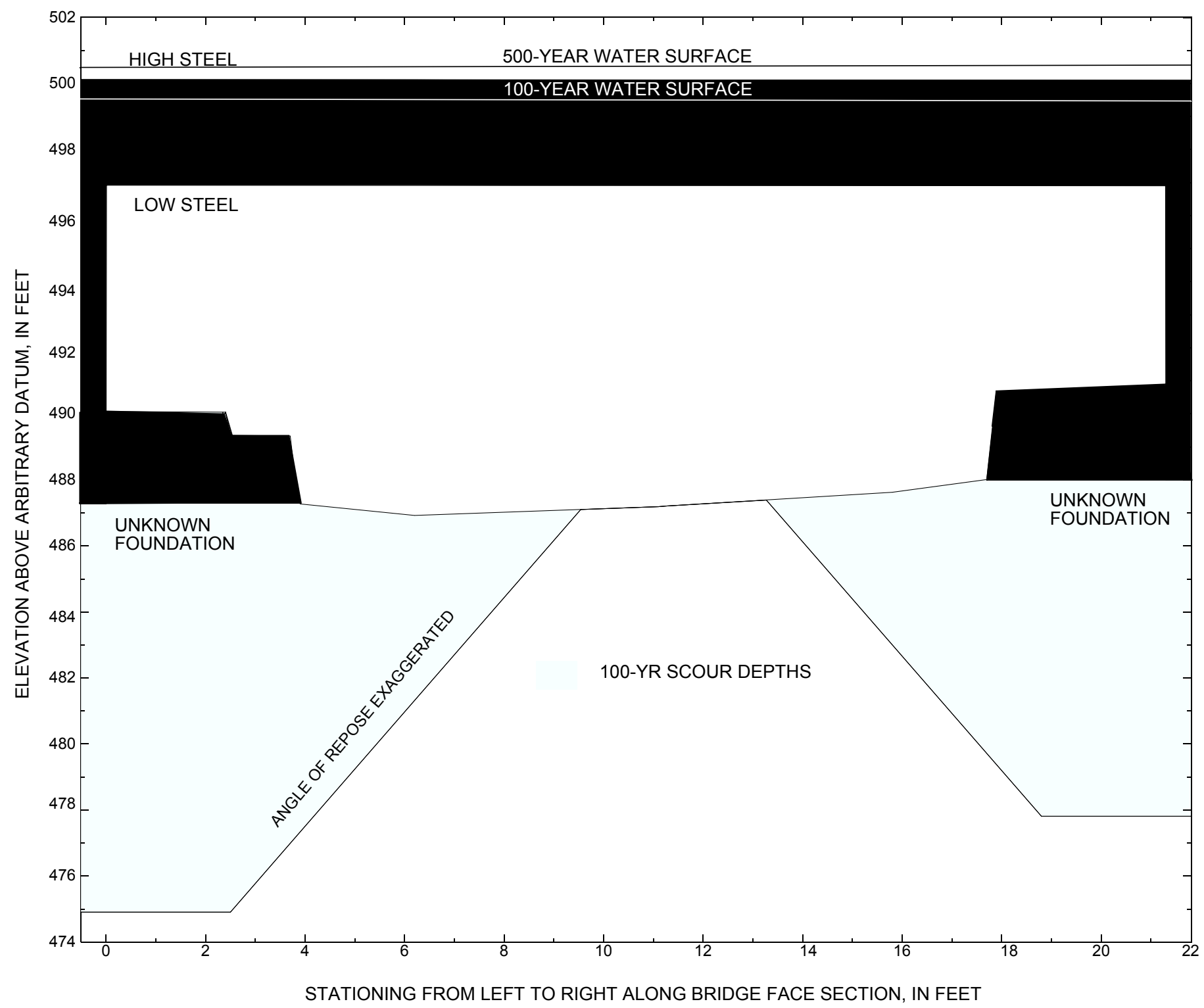

Figure 8. Scour elevations for the 100-yr and 500-yr discharges at structure BETHTH00070037 on town highway 7, crossing Gilead Brook, Bethel, Vermont. 
Table 1. Remaining footing/pile depth at abutments for the 100-year discharge at structure BETHTH00070037 on Town Highway 7, crossing Gilead Brook, Bethel, Vermont. [VTAOT, Vermont Agency of Transportation; --,no data]

\begin{tabular}{|c|c|c|c|c|c|c|c|c|c|c|c|}
\hline Description & Station ${ }^{1}$ & $\begin{array}{l}\text { VTAOT } \\
\text { minimum } \\
\text { low-chord } \\
\text { elevation } \\
\text { (feet) }\end{array}$ & $\begin{array}{l}\text { Surveyed } \\
\text { minimum } \\
\text { low-chord } \\
\text { elevation } \\
\quad \text { (feet) }\end{array}$ & $\begin{array}{l}\text { Bottom of } \\
\text { footing } \\
\text { elevation } \\
\text { (feet) }\end{array}$ & $\begin{array}{c}\text { Channel } \\
\text { elevation at } \\
\text { abutment/ } \\
\text { pier }^{2} \\
\text { (feet) }\end{array}$ & $\begin{array}{l}\text { Contraction } \\
\text { scour depth } \\
\text { (feet) }\end{array}$ & $\begin{array}{l}\text { Abutment } \\
\text { scour } \\
\text { depth } \\
\text { (feet) }\end{array}$ & $\begin{array}{l}\text { Pier } \\
\text { scour } \\
\text { depth } \\
\text { (feet) }\end{array}$ & $\begin{array}{l}\text { Depth of } \\
\text { total scour } \\
\text { (feet) }\end{array}$ & $\begin{array}{c}\text { Elevation of } \\
\text { scour }^{2} \\
\text { (feet) }\end{array}$ & $\begin{array}{c}\text { Remaining } \\
\text { footing/pile } \\
\text { depth } \\
\text { (feet) }\end{array}$ \\
\hline \multicolumn{12}{|c|}{100 -yr. discharge is 1,700 cubic-feet per second } \\
\hline Left abutment & 0.0 & -- & 496.9 & -- & 487.3 & 0.0 & 12.4 & -- & 12.4 & 474.9 & -- \\
\hline Right abutment & 21.3 & -- & 496.8 & -- & 488.0 & 0.0 & 10.2 & -- & 10.2 & 477.8 & -- \\
\hline
\end{tabular}

1. Measured along the face of the most constricting side of the bridge.

2. Arbitrary datum for this study.

Table 2. Remaining footing/pile depth at abutments for the 500-year discharge at structure BETHTH00070037 on Town Highway 7, crossing Gilead Brook, Bethel, Vermont. [VTAOT, Vermont Agency of Transportation; --, no data]

\begin{tabular}{|c|c|c|c|c|c|c|c|c|c|c|c|}
\hline Description & Station $^{1}$ & $\begin{array}{l}\text { VTAOT } \\
\text { minimum } \\
\text { low-chord } \\
\text { elevation } \\
\text { (feet) }\end{array}$ & $\begin{array}{l}\text { Surveyed } \\
\text { minimum } \\
\text { low-chord } \\
\text { elevation } \\
\text { (feet) }\end{array}$ & $\begin{array}{c}\text { Bottom of } \\
\text { footing } \\
\text { elevation } \\
\text { (feet) }\end{array}$ & $\begin{array}{c}\text { Channel } \\
\text { elevation at } \\
\text { abutment/ } \\
\text { pier }^{2} \\
\text { (feet) }\end{array}$ & $\begin{array}{c}\text { Contraction } \\
\text { scour depth } \\
\text { (feet) }\end{array}$ & $\begin{array}{l}\text { Abutment } \\
\text { scour } \\
\text { depth } \\
\text { (feet) }\end{array}$ & $\begin{array}{l}\text { Pier } \\
\text { scour } \\
\text { depth } \\
\text { (feet) }\end{array}$ & $\begin{array}{l}\text { Depth of } \\
\text { total scour } \\
\text { (feet) }\end{array}$ & $\begin{array}{c}\text { Elevation of } \\
\text { scour }^{2} \\
\text { (feet) }\end{array}$ & $\begin{array}{c}\text { Remaining } \\
\text { footing/pile } \\
\text { depth } \\
\text { (feet) }\end{array}$ \\
\hline \multicolumn{12}{|c|}{500 -yr. discharge is 2,200 cubic-feet per second } \\
\hline Left abutment & 0.0 & -- & 496.9 & -- & 487.3 & 0.0 & 10.2 & -- & 10.2 & 477.1 & -- \\
\hline Right abutment & 21.3 & -- & 496.8 & -- & 488.0 & 0.0 & 8.8 & -- & 8.8 & 479.2 & -- \\
\hline
\end{tabular}

${ }^{1}$ Measured along the face of the most constricting side of the bridge.

2. Arbitrary datum for this study. 


\section{SELECTED REFERENCES}

Arcement, G.J., Jr., and Schneider, V.R., 1989, Guide for selecting Manning's roughness coefficients for natural channels and flood plains: U.S. Geological Survey Water-Supply Paper 2339, 38 p.

Barnes, H.H., Jr., 1967, Roughness characteristics of natural channels: U.S. Geological Survey Water-Supply Paper 1849, 213 p.

Brown, S.A. and Clyde, E.S., 1989, Design of riprap revetment: Federal Highway Administration Hydraulic Engineering Circular No. 11, Publication FHWA-IP-89-016, 156 p.

Federal Highway Administration, 1983, Runoff estimates for small watersheds and development of sound design: Federal Highway Administration Report FHWA-RD-77-158

Froehlich, D.C., 1989, Local scour at bridge abutments in Ports, M.A., ed., Hydraulic Engineering--Proceedings of the 1989 National Conference on Hydraulic Engineering: New York, American Society of Civil Engineers, p. 13-18.

Hayes, D.C.,1993, Site selection and collection of bridge-scour data in Delaware, Maryland, and Virginia: U.S. Geological Survey WaterResources Investigation Report 93-4017, 23 p.

Interagency Advisory Committee on Water Data, 1982, Guidelines for determining flood flow frequency: U.S. Geological Survey, Bulletin 17B of the Hydrology Subcommittee, 190 p.

Johnson, C.G. and Tasker, G.D.,1974, Progress report on flood magnitude and frequency of Vermont streams: U.S. Geological Survey Open-File Report 74-130, 37 p.

Laursen, E.M., 1960, Scour at bridge crossings: Journal of the Hydraulics Division, American Society of Civil Engineers, v. 86, no. HY2, p. 39-53.

Potter, W. D., 1957a, Peak rates of runoff in the Adirondack, White Mountains, and Maine woods area, Bureau of Public Roads

Potter, W. D., 1957b, Peak rates of runoff in the New England Hill and Lowland area, Bureau of Public Roads

Richardson, E.V., and Davis, S.R., 1995, Evaluating scour at bridges: Federal Highway Administration Hydraulic Engineering Circular No. 18, Publication FHWA-IP-90-017, 204 p.

Richardson, E.V., Harrison, L.J., Richardson, J.R., and Davis, S.R., 1993, Evaluating scour at bridges: Federal Highway Administration Hydraulic Engineering Circular No. 18, Publication FHWA-IP-90-017, 131 p.

Richardson, E.V., Simons, D.B., and Julien, P.Y., 1990, Highways in the river environment: Federal Highway Administration Publication FHWA-HI-90-016.

Ritter, D.F., 1984, Process Geomorphology: W.C. Brown Co., Debuque, Iowa, 603 p.

Shearman, J.O., 1990, User's manual for WSPRO--a computer model for water surface profile computations: Federal Highway Administration Publication FHWA-IP-89-027, 187 p.

Shearman, J.O., Kirby, W.H., Schneider, V.R., and Flippo, H.N., 1986, Bridge waterways analysis model; research report: Federal Highway Administration Publication FHWA-RD-86-108, 112 p.

Talbot, A.N., 1887, The determination of water-way for bridges and culverts.

U.S. Department of Transportation, 1993, Stream stability and scour at highway bridges, Participant Workbook: Federal Highway Administration Publication FHWA HI-91-011.

U.S. Geological Survey, 1981, Randolph, Vermont 7.5 Minute Series quadrangle map: U.S. Geological Survey Topographic Maps, Scale $1: 24,000$. 


\section{APPENDIX A: \\ WSPRO INPUT FILE}




\section{WSPRO INPUT FILE}

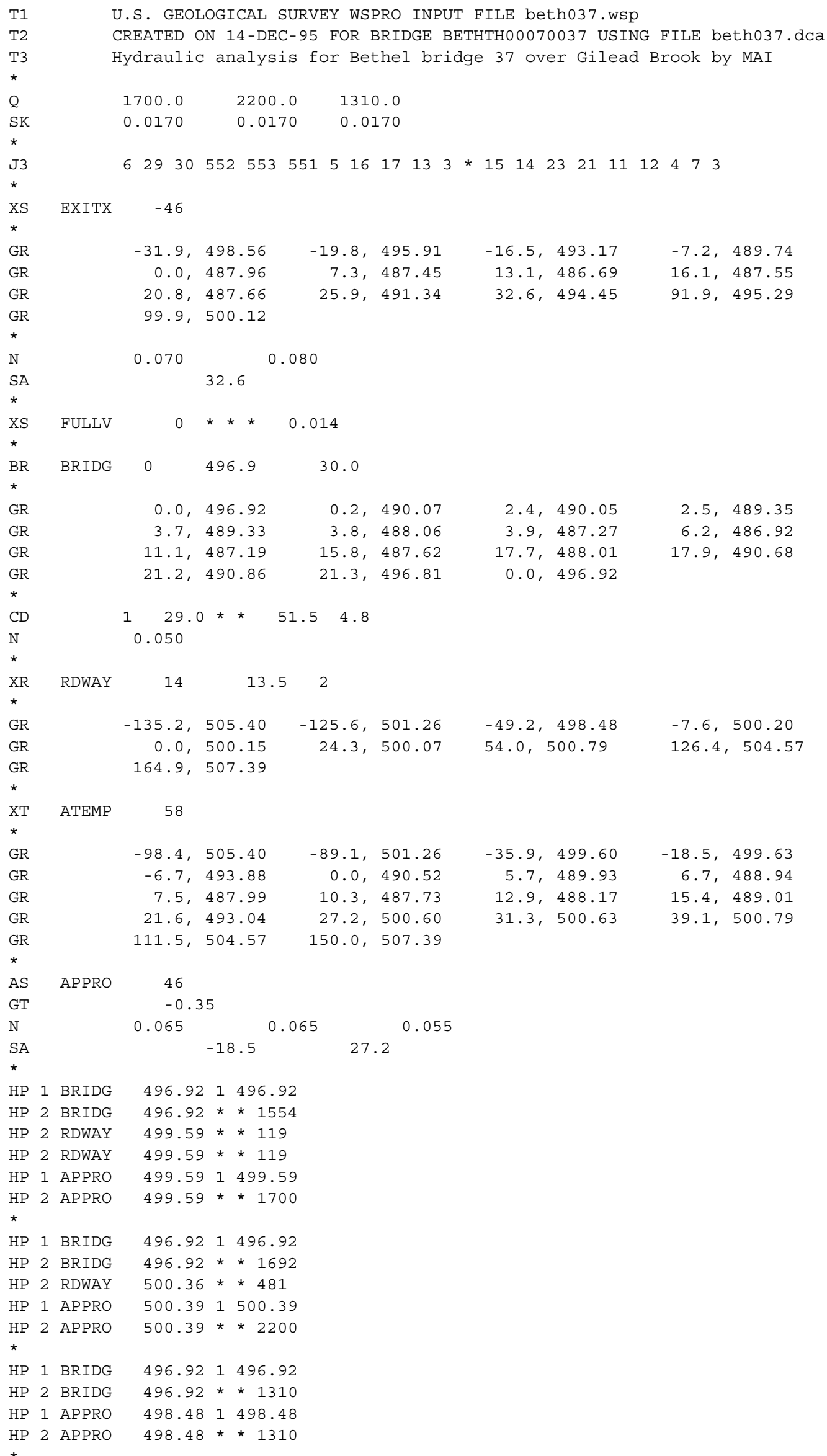




\section{APPENDIX B: \\ WSPRO OUTPUT FILE}




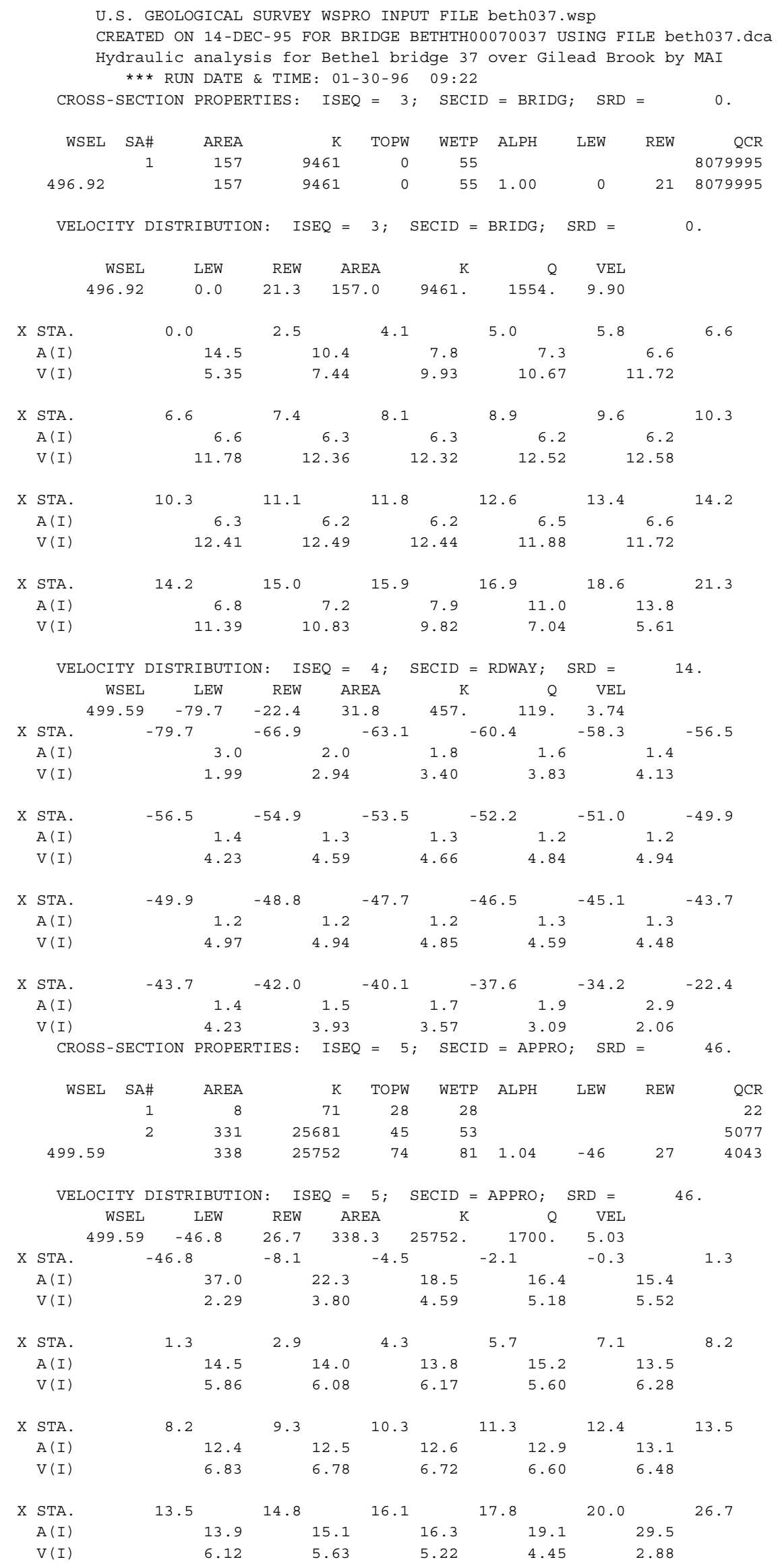


WSPRO OUTPUT FILE (continued)

\begin{tabular}{|c|c|c|c|c|c|c|c|c|c|c|c|}
\hline & CROSS-SEC & ECTION & PROPER & TIES: & ISEQ & $=$ & SECI & $D=B R I D G ;$ & SRD & $=$ & 0 . \\
\hline & WSEL SA & SA\# & AREA & & $\mathrm{K}$ & TOPW & WETP & $\mathrm{ALPH}$ & LEW & REW & QCR \\
\hline & & 1 & 157 & & 9461 & 0 & 55 & & & & 8079995 \\
\hline & 496.92 & & 157 & & 9461 & 0 & 55 & 1.00 & 0 & 21 & 8079995 \\
\hline & VELOCITY & Y DISTH & RIBUTIO & & $\mathrm{ISEQ}=$ & $3 ;$ & SECID $=$ & $=$ BRIDG; & $\mathrm{SRD}=$ & & 0. \\
\hline & WSEI & & LEW & REW & $\mathrm{AR}$ & EA & $\mathrm{K}$ & $Q$ & VEL & & \\
\hline & 496.92 & & 0.0 & 21.3 & 157 & & 9461. & 1692. & 10.78 & & \\
\hline $\mathrm{x}$ & STA. & 0.0 & & 2.5 & & 4.1 & & 5.0 & 5.8 & & 6.6 \\
\hline & $A(I)$ & & 14.5 & & 10.4 & & 7.8 & 7.3 & & 6.6 & \\
\hline & $V(I)$ & & 5.82 & & 8.11 & & 10.82 & 11.62 & & 12.76 & \\
\hline $\mathrm{X}$ & STA. & 6.6 & & 7.4 & & 8.1 & & 8.9 & 9.6 & & 10.3 \\
\hline & $A(I)$ & & 6.6 & & 6.3 & & 6.3 & 6.2 & & 6.2 & \\
\hline & $V(I)$ & & 12.83 & & 13.46 & & 13.42 & 13.64 & & 13.70 & \\
\hline $\mathrm{X}$ & STA. & 10.3 & & 11.1 & & 11.8 & & 12.6 & 13.4 & & 14.2 \\
\hline & $A(I)$ & & 6.3 & & 6.2 & & 6.2 & 6.5 & & 6.6 & \\
\hline & $V(I)$ & & 13.52 & & 13.60 & & 13.54 & 12.93 & & 12.77 & \\
\hline $\mathrm{X}$ & STA. & 14.2 & & 15.0 & & 15.9 & & 16.9 & 18.6 & & 21.3 \\
\hline & $A(I)$ & & 6.8 & & 7.2 & & 7.9 & 11.0 & & 13.8 & \\
\hline & $V(I)$ & & 12.40 & & 11.79 & & 10.69 & 7.66 & & 6.11 & \\
\hline & VELOCITY & I DISTR & RIBUTIO & $\mathrm{N}:$ & ISEQ $=$ & $4 ;$ & SECID $=$ & $=$ RDWAY; & $\mathrm{SRD}=$ & & 14. \\
\hline & WSEI & & LEW & REW & $\mathrm{AR}$ & EA & K & $Q$ & VEL & & \\
\hline & 500.36 & $\begin{array}{ll}36 & -10\end{array}$ & 00.9 & 36.3 & 100 & .2 & 1757. & 481. & 4.80 & & \\
\hline $\mathrm{X}$ & STA. & -100.9 & & -79.9 & & -73.7 & & 69.3 & -65.8 & & -62.8 \\
\hline & $A(I)$ & & 8.0 & & 5.5 & & 4.7 & 4.3 & & 3.9 & \\
\hline & $V(I)$ & & 3.02 & & 4.38 & & 5.14 & 5.63 & & 6.13 & \\
\hline $\mathrm{x}$ & STA. & -62.8 & & -60.1 & & -57.7 & & -55.4 & -53.3 & & -51.3 \\
\hline & $A(I)$ & & 3.9 & & 3.7 & & 3.6 & 3.6 & & 3.6 & \\
\hline & $V(I)$ & & 6.19 & & 6.51 & & 6.60 & 6.61 & & 6.73 & \\
\hline $\mathrm{X}$ & STA. & -51.3 & & -49.3 & & -47.3 & & -45.0 & -42.6 & & -39.8 \\
\hline & $A(I)$ & & 3.7 & & 3.7 & & 3.9 & 4.0 & & 4.4 & \\
\hline & $V(I)$ & & 6.57 & & 6.57 & & 6.14 & 5.97 & & 5.51 & \\
\hline $\mathrm{X}$ & STA. & -39.8 & & -36.4 & & -32.3 & & -26.7 & -16.4 & & 36.3 \\
\hline & $A(I)$ & & 4.8 & & 5.3 & & 5.9 & 7.6 & & 12.2 & \\
\hline & $V(I)$ & & 5.04 & & 4.58 & & 4.06 & 3.15 & & 1.97 & \\
\hline & CROSS-SEC & ECTION & PROPER & TIES : & ISEQ & $=5 ;$ & SECI & $D=A P P R O ;$ & SRD & $=$ & 46. \\
\hline & WSEL SA & SA\# & AREA & & $\mathrm{K}$ & TOPW & WETP & ALPH & LEW & REW & $\mathrm{QCR}$ \\
\hline & & 1 & 40 & & 764 & 54 & 54 & & & & 198 \\
\hline & & 2 & 367 & & 30250 & 46 & 54 & & & & 5906 \\
\hline & & 3 & 1 & & 4 & 9 & 9 & & & & 1 \\
\hline & 500.39 & & 408 & & 31018 & 109 & 117 & 1.15 & -71 & 37 & 4183 \\
\hline & VELOCITY & DISTR & RIBUTIO & & ISEQ $=$ & $5 ;$ & SECID $=$ & $=$ APPRO; & $\mathrm{SRD}=$ & & 46. \\
\hline & WSEI & & LEW & REW & AR & $\mathrm{EA}$ & $\mathrm{K}$ & $Q$ & VEL & & \\
\hline & 500.39 & & 72.4 & 36.7 & 408 & & 31018. & 2200. & 5.39 & & \\
\hline $\mathrm{x}$ & STA. & -72.4 & & -11.5 & & -6.8 & & -3.9 & -1.7 & & 0.1 \\
\hline & $A(I)$ & & 60.3 & & 26.2 & & 22.1 & 19.4 & & 17.9 & \\
\hline & $V(I)$ & & 1.83 & & 4.21 & & 4.98 & 5.66 & & 6.16 & \\
\hline $\mathrm{X}$ & STA. & 0.1 & & 1.7 & & 3.3 & & 4.7 & 6.2 & & 7.6 \\
\hline & $A(I)$ & & 16.9 & & 15.8 & & 15.5 & 16.2 & & 16.9 & \\
\hline & $V(I)$ & & 6.50 & & 6.95 & & 7.09 & 6.81 & & 6.53 & \\
\hline $\mathrm{X}$ & STA. & 7.6 & & 8.7 & & 9.8 & & 10.9 & 12.1 & & 13.3 \\
\hline & $A(I)$ & & 14.4 & & 14.5 & & 14.2 & 14.9 & & 15.2 & \\
\hline & $V(I)$ & & 7.65 & & 7.59 & & 7.74 & 7.40 & & 7.26 & \\
\hline $\mathrm{X}$ & STA. & 13.3 & & 14.6 & & 16.1 & & 17.8 & 20.2 & & 36.7 \\
\hline & $A(I)$ & & 16.1 & & 17.0 & & 18.9 & 22.1 & & 34.1 & \\
\hline & $V(I)$ & & 6.84 & & 6.45 & & 5.83 & 4.97 & & 3.22 & \\
\hline
\end{tabular}


WSPRO OUTPUT FILE (continued)

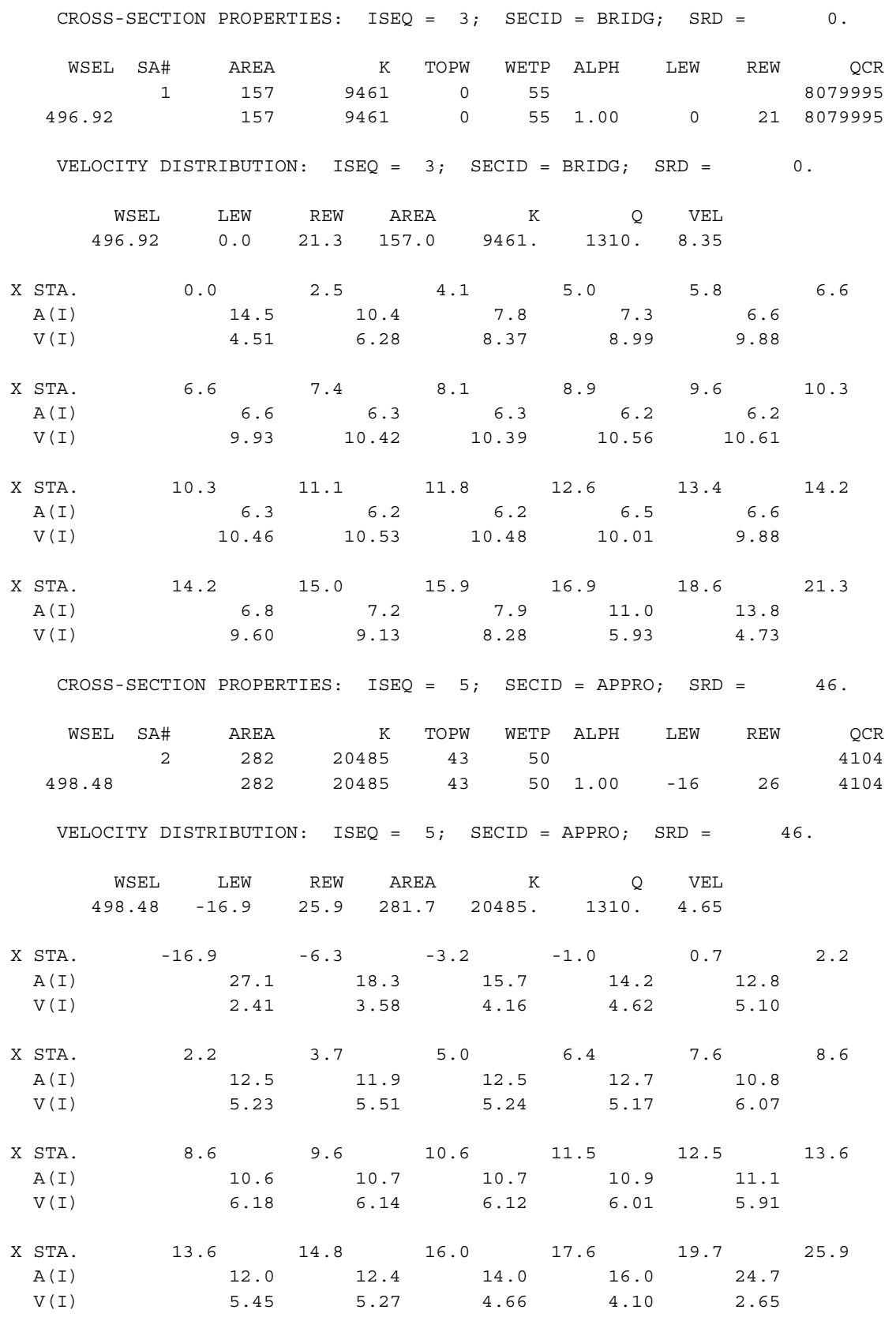


WSPRO OUTPUT FILE (continued)

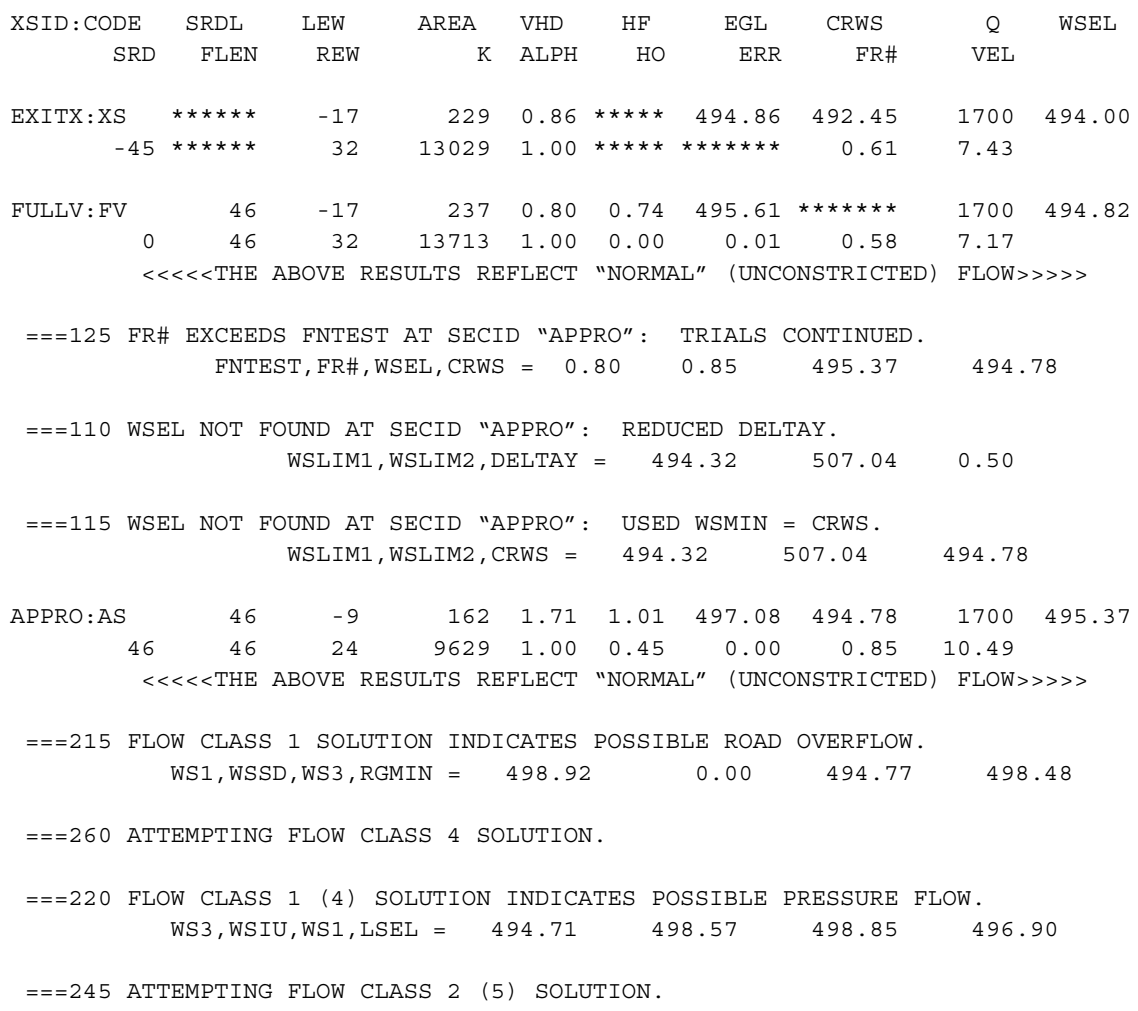


WSPRO OUTPUT FILE (continued)

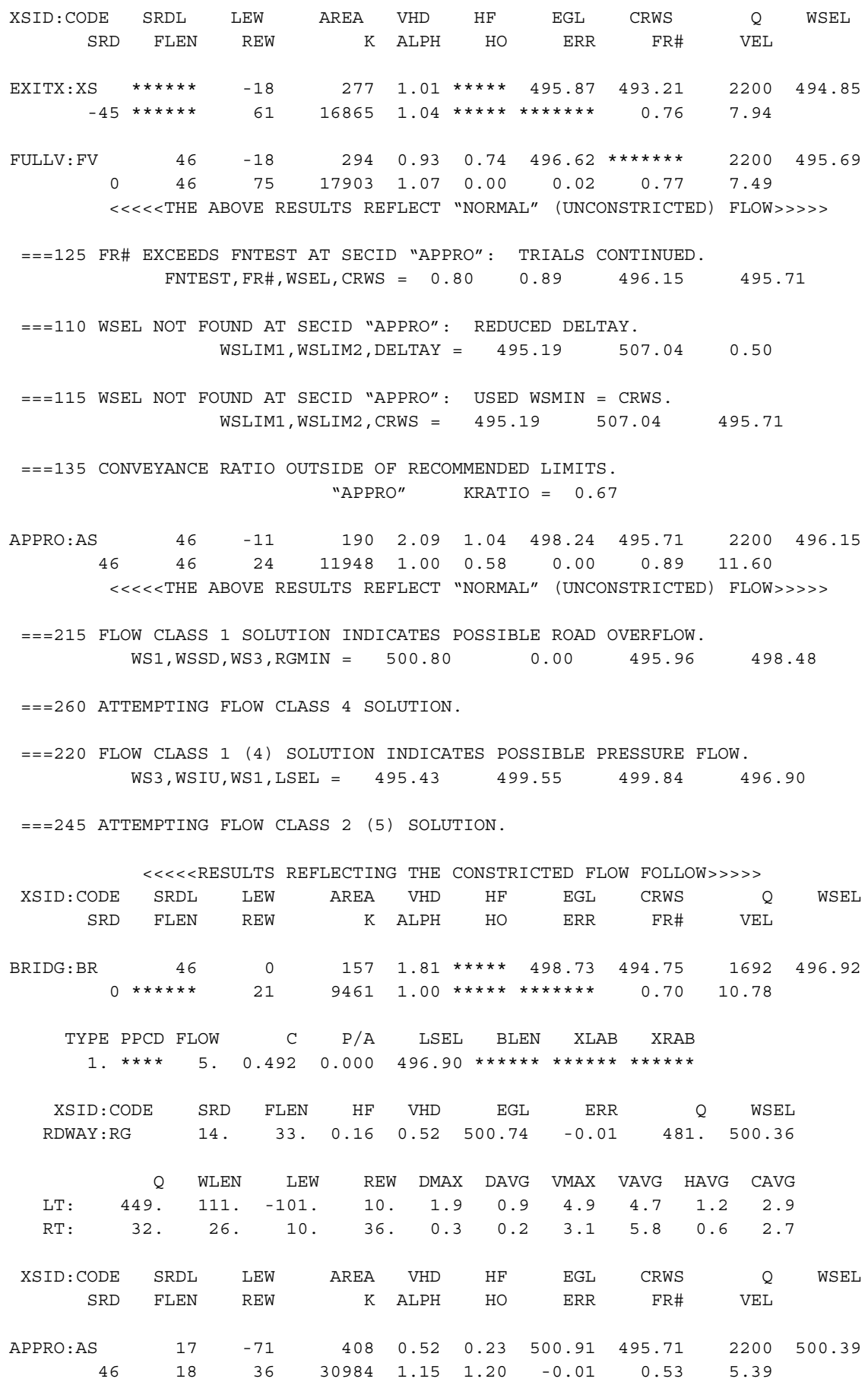

FIRST USER DEFINED TABLE.

$\begin{array}{lrrrrrrrr}\text { XSID }: \text { CODE } & \text { SRD } & \text { LEW } & \text { REW } & \text { Q } & \text { K } & \text { AREA } & \text { VEL } & \text { WSEL } \\ \text { EXITX : XS } & -46 . & -19 . & 61 . & 2200 . & 16865 . & 277 . & 7.94 & 494.85 \\ \text { FULLV }: \text { FV } & 0 . & -19 . & 75 . & 2200 . & 17903 . & 294 . & 7.49 & 495.69 \\ \text { BRIDG : BR } & 0 . & 0 . & 21 . & 1692 . & 9461 . & 157 . & 10.78 & 496.92 \\ \text { RDWAY : RG } & 14 . * * * * * * & 449 . & 481 . * * * * * * * * & 0 . & 2.00 & 500.36 \\ \text { APPRO : AS } & 46 . & -72 . & 36 . & 2200 . & 30984 . & 408 . & 5.39 & 500.39\end{array}$

SECOND USER DEFINED TABLE.

$\begin{array}{lrrrrrrrrr}\text { XSID : CODE } & \text { CRWS } & \text { FR\# } & \text { YMIN } & \text { YMAX } & \text { HF } & \text { HO } & \text { VHD } & \text { EGL } & \text { WSEL } \\ \text { EXITX:XS } & 493.21 & 0.76 & 486.69 & 500.12 * * * * * * * * * * * & 1.01 & 495.87 & 494.85 \\ \text { FULLV:FV } & * * * * * * * * & 0.77 & 487.33 & 500.76 & 0.74 & 0.00 & 0.93 & 496.62 & 495.69 \\ \text { BRIDG : BR } & 494.75 & 0.70 & 486.92 & 496.92 * * * * * * * * * * * & 1.81 & 498.73 & 496.92 \\ \text { RDWAY: RG } & * * * * * * * * * * * * * * * & 498.48 & 507.39 & 0.16 * * * * * * & 0.52 & 500.74 & 500.36 \\ \text { APPRO:AS } & 495.71 & 0.53 & 487.38 & 507.04 & 0.23 & 1.20 & 0.52 & 500.91 & 500.39\end{array}$


WSPRO OUTPUT FILE (continued)

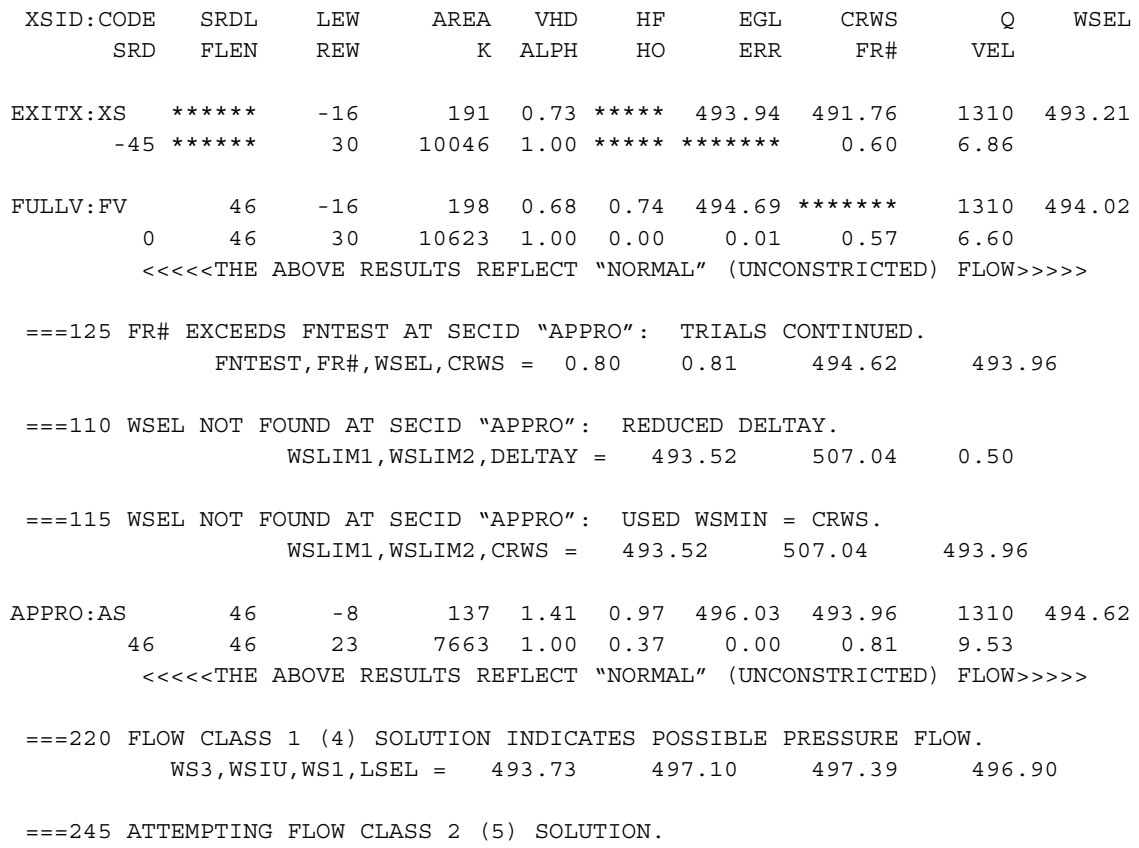




\section{APPENDIX C:}

\section{BED-MATERIAL PARTICAL-SIZE DISTRIBUTION}




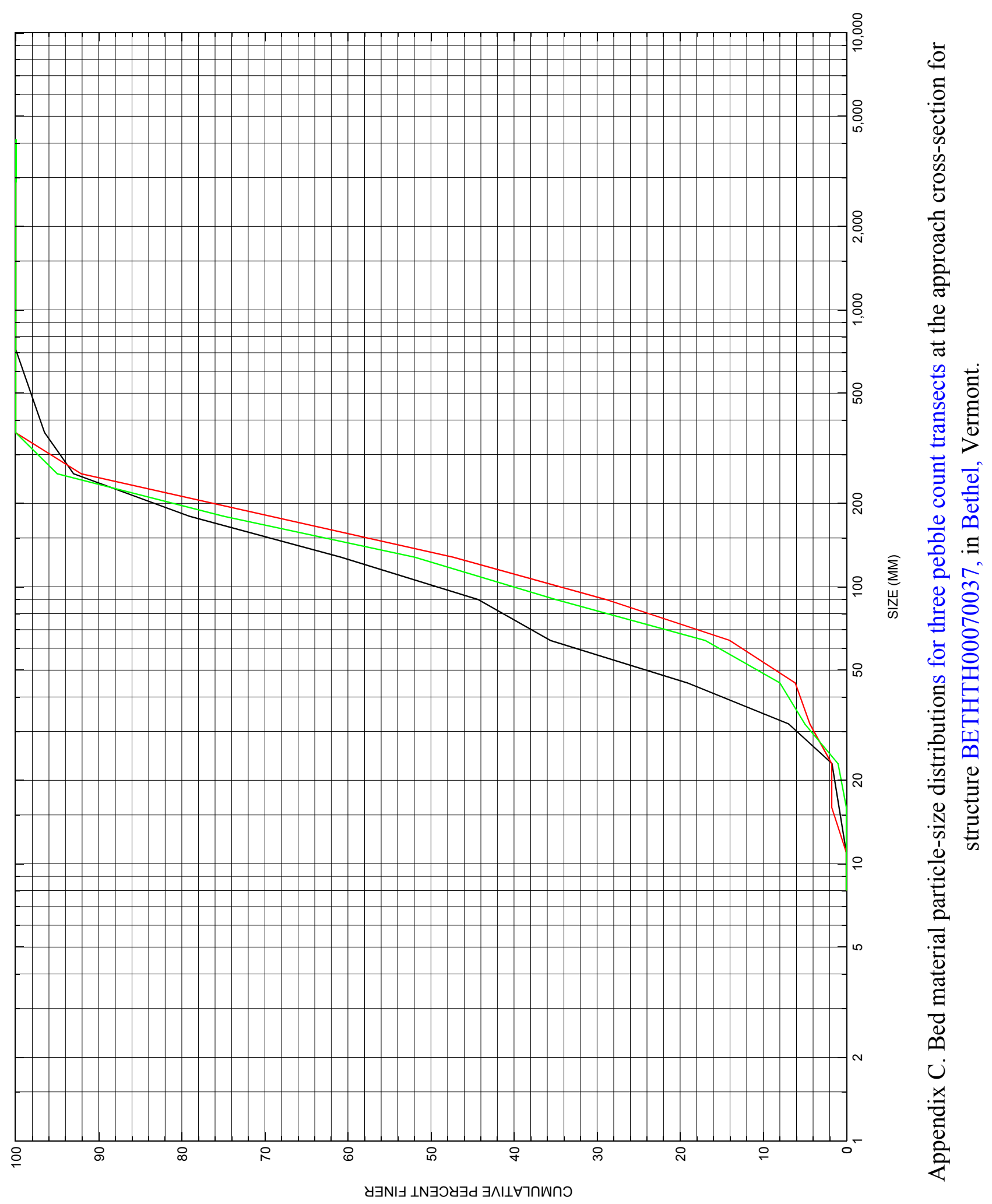




\section{APPENDIX D: \\ HISTORICAL DATA FORM}

